\title{
PENERAPAN MODEL VIEW CONTROLLER (MVC) UNTUK PERANCANGAN SISTEM RUANG BUKU INDONESIA
}

\author{
Maria Ulfa ${ }^{1}$, Suryayusra $^{2}$, Septa Hardini ${ }^{3}$
}

1,2,3 Universitas Bina Darma

Jln. Jendral A. Yani, No.03, Kota Palembang, Indonesia

${ }^{1}$ maria.ulfa@binadarma.ac.id, ${ }^{2}$ suryayusra@binadarma.ac.id, ${ }^{3}$ septa.hardini@binadarma.ac.id

\begin{abstract}
Abstrak-E-commerce merupakan suatu sistem penjualan berbasis online, yang digunakan untuk memperluas penjualan dan meningkatkan penjualan pada CV Ruang Buku Indonesia. Dalam segi penjualan sekarang CV Ruang Buku Indonesia memiliki banyak pesaing yang memanfaatkan teknologi internet sehingga menjadikan usaha ini tertinggal dan proses penjualan dan pembeliannya menjadi kurang maksimal, bahkan menurun. Hal seperti ini bisa mengakibatkan suatu usaha menjadi tutup. Berdasarkan hal tersebut maka dilakukan pengembangan dalam sistem penjualan menjadi e-commerce dengan model view controller (MVC) untuk mempermudah dalam pengoperasian sistem penjualan online. Model pengembangan perangkat lunak yang digunakan adalah model waterfall dengan beberapa tahapan communication, planning, modelling, construction, dan deployment. Penelitian ini menghasilkan e-commerce Ruang Buku Indonesia dengan model view controller yang bertujuan untuk untuk menghadapi pesaing dan meningkatkan penjualan.
\end{abstract}

Kata Kunci-Penjualan, e-commerce, MVC, waterfall

Abstract-E-commerce is an online-based sales system, which is used to expand sales and increase sales in the Indonesian Book Room CV. In terms of sales now CV Ruang Buku Indonesia has many competitors who use internet technology to make this business lag and the sales and purchase processes are less than optimal, even decreased. Things like this can cause a business to close. Based on this, the development in the sales system is made into e-commerce with a view controller model (MVC) to facilitate the operation of the online sales system. The software development model used is the waterfall model with several stages of communication, planning, modeling, construction, and deployment. This research resulted in e-commerce of Indonesian Book Room with a view controller model that aims to face competitors and increase sales.

Keywords-Sales, e-commerce, MVC, waterfall

\section{PENDAHULUAN}

Information Technology (IT) sekarang ini mengalami kemajuan khususnya penggguna teknologi internet. Kemajuan teknologi ini dapat dimanfaatkan oleh berbagai usaha untuk perkembangan dan kemajuan usahanya bahkan banyak pesaing-pesaing usaha yang berpotensi dalam menggunakan teknologi tersebut. kemajuan teknologi tersebut juga bisa dijadikan sebagai kekuatan utama bagi perusahaan untuk memajukan usaha dengan didukung oleh kemanpuan sumber daya manusia (SDM) dan sistem yang memadai. Sistem yang bisa dimanfaatkan antara lain e-commerce dan pedagaangan online. e-commerce merupakan media perdangan elektorik yang memiliki karakteristik atau sifat-sifat tertentu [1].

CV Ruang Buku Indonesia merupakan suatu usaha yang bergerak dibidang jasa dan penjualan buku antara lain buku untuk Pendidikan Anak Usia Dini (PAUD), Pendidikan Sekolah Dasar (SD), Ilmu Komputer, Olahraga, Fisika, dan Buku Umum. CV Ruang Buku Indonesia dalam proses penjualan dilakukan secara langsung bertemu antara penjual dan pembeli, sehingga dilakukan pengembangan dalam proses penjualan dengan manfaatkan perkembangan teknologi. Proses seperti ini akan menjadikan usaha tertinggal dan proses penjualan dan pembeliannya menjadi kurang maksimal, bahkan menurun.

Pada penelitian ini sistem penjualan akan dikembangkan menjadi sistem penjualan online ( $e$ commerce) menggunakan model view controller $(M V C)$. MVC ialah teknik pemrograman yang expect programmer secara disiplin untuk dibagi menjadi 3 bagian yaitu model-view-controller [2]. Berdasarkan penjelasan diatas, maka peneliti memanfaatkan model view controller $(M V C)$ pada e-commerce CV Ruang Buku Indonesia. Tujuan penelitian ini untuk meningkatkan penjualan, mempermudah melakukan jual beli secara online dengan memanfaatkan model view controller.

Hasil survey bekerja sama dengan Teknopreneur mengemukakan, penetrasi pemakai internet tahun 2017, lebih dari 54,7 persen atau sekitar 143,36 juta orang yang terhubung dengan internet, dari total populasi penduduk Indonesia 262 juta orang, pada survey yang sama pada tahun 2016 ke tahun 2017", 
menurut Henry K Soemartono, Sekretaris Jendral Asosiasi Penyelenggara Jasa Internet Indonesia (APJII) (APJII, 2018).

Adapun penelitian sebelumnya yang dijadikan sebagai refrensi antara lain adalah: "Implementasai

Page|54 model view controller menggunakan framework codeigniter pada e-commerce kerajinan bali" [3]. Kesimpulan yang dihasilkan adalah sebuat aplikasi ecommerce kerajinan bali dengan framework codelgniter. Memberikan kemudahan kepada customer dalam proses pembelian atau pemesanan kerajinan bali secara online. "Perancangan information systems penjualan berbasis framework model view controller $(M C V)$ pada PT Thamrin Brother cabang OKI" [4]. Kesimpulan dari pembahasa penelitian ini adalah menghasilkan desain information systems penjualan berbasis MVC. Memberikan kemudahan admin dalam management sistem serta memberi kemudahan dalam penjualan secara online. Penelitian yang dilakukan Zulfikar dkk [5] dan Solikin dkk [6]. Aplikasi antrian poliklinik pasien dapat digunakan untuk mempermudah calon pasien poliklinik dalam melakukan pendaftaran tanpa perlu mendatangi ataupun memnghubungi pihak poliklinik. Sistem ini juga memberikan informasi antrian secara langsung sehingga calon pasien dapat mengawasi jalannya antrian tanpa perlu berada di lokasi antrian. "Systems rekomendasi pada e-commerce berbasis $k$-nearest neighbor" [7]. Dari penelitian yang terkait pada penelitian petama sampai penelitian keempat menguatkan kearah e-commerce dan model view controller tetapi pada tidak menggunakan model view controller. "Pengambangan design sistem informasi kesiswaan berbasis framework MVC (model view controller)" [8]. Kesimpulan yang diperoleh dari penelitian ini berupa implementasi information systems administrasi kesiswaan pada SMK Al Muhadjirin 2 Bekasi sehingga bisa mempercepat dalam search process data seperti nilai siswa ataupun absensi siswa. Menjadi sarana dalam meningkatkan akreditasi sekolah, serta kedisiplinan dalam pembelajaran. "Implementasi model view controller $(M V C)$ dalam design aplikasi webgis sebagai information rentan banjir di Semarang" [9]. Kesimpulan yang diperoleh dari penelitian ini berupa implementasi arsitektur MVC dalam pemodelan aplikasi webgis sebagai information rentan banjir di Semarang. Arsitektur MVC dapat mengurangi secara signifikan kerumitan koding dalam aplikasi. Meningkatkan fleksibilitas aplikasi yang dibangun yang dalam hal ini berupa webgis. pada penelitin keenam ini menjadi refrensi bagian model view controller.

\section{METODOLOGI PENELITIAN}

Research methods dan development merupakan metode yang digunakan dalam penelitian untuk menghasilkan suatu produk tertentu, dan testing kelayakan dari keefektifan suatu produk yang dihasilkan sehingga menjadi produk yang bisa digunakan [9].

\section{A. Teknik Pengumpulan Data}

Interview, teknik ini ialah pengumpulan data yang datanya diperoleh dari responden secara mendalam dan berkaitan dengan penelitian untuk menemukan suatu permasalahan serta pontensi yang harus diteliti [11]. Wawancara dilakukan kepada Bangkit Seandi Taroreh yang merupakan pemilik CV Ruang Buku Indonesia. Wawancara dilakukan pada tanggal 24 Desember 2019. Inti dari wawancara yaitu mengenai katagori buku, proses penjualan buku, berapa buku terjual dan luas penjualan buku.

Observasi, teknik ini merupakan pengumpulan data melalui pengamatan secara langsung atau melihat langsung tanpa menggunakan bantuan alat standar lain untuk tujuan tersebut [12]. Proses pengamatan ini berupa pengamatan langsung dalam proses penjual, barang yang dijual dan mengamati barang yang ada di CV Ruang Buku Indonesia.

\section{B. Model View Controller (MVC)}

MVC adalah cara pemrograman yang expect programmer secara disiplin untuk dibagi menjadi 3 bagian, diantaranya model-view-controller [2], siklus model tersebut dapat dilihat pada gambar 1 .

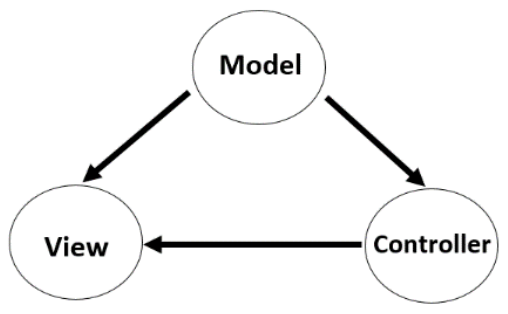

Gbr. 1 Siklus model view controller

\section{Model Waterfall}

Model waterfall bersifat sistematis atau berurutan dalam membangun software dan merupakan model klasik [13]. Dinamakan dengan model waterfall karena dalam penyelesaianya harus melalui tahap ketahap berikutnya dan dikerjakan secara berurutan. Model waterfall mempunyai fase-fase, yang bisa dilihat pada gambar 2 .

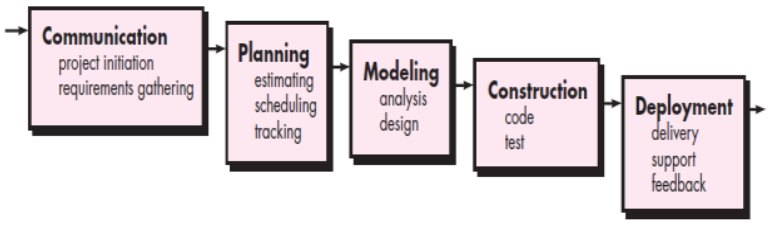

Gbr. 2 Model waterfall

1. Communication (project initiation \& requirements gathering), pada tahap ini peneliti melakukan analisis permasalahan yang dihadapi CV Ruang Buku Indonesia dan requirements data yang digunakan, serta mendefinisikan fitur dan software. 
2. Planning (estimating, scheduling, tracking), ada tahap ini peneliti melakukan penjadwalan proses kerja dalam implementasi e-commerce pada CV Ruang Buku Indonesi dan mengecek proses pengerjaan sistem tersebut.

Page|55 3. Modeling (analysis dan design), tahap ini peneliti melakukan design dan pemodelan arsitektur software yang berfokus ke algoritma program, design struktur data, arsitektur software, dan design interface.

Sistem kerja menggunakan model view controller yang ada digambar 3 yaitu : pada bagian view menangani presentasi logic yang berfungsi dalam menerima serta mereprentasikan data kepada user, view mempunyai access secara langsung kebagian model. Pada bagian model secara langsung berhubungan dengan database untuk manipulate data (input, update, delete, dan search), melakukan validasi melalui bagian controller, tetapi tidak bisa secara langsung berhubungan dengan bagian view. Controller melakukan setting hubungan dengan bagian model serta bagian view. Pada view mempunyai fungsi dalam menerima request dan data dari user selanjutnya menentukan apa yang ingin diproses oleh software.

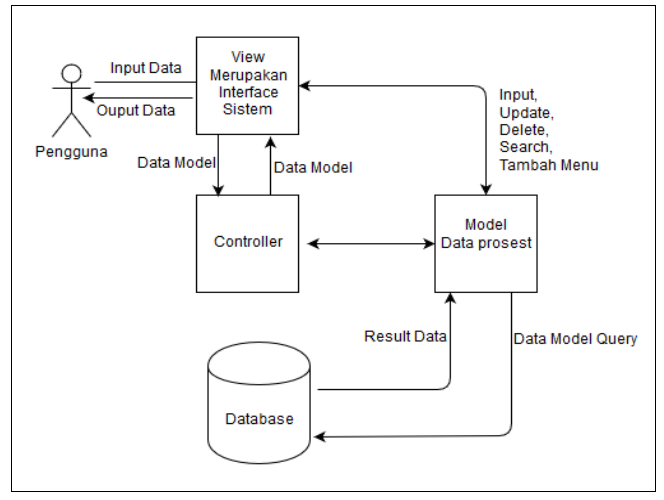

Gbr. 3 Diagram MVC

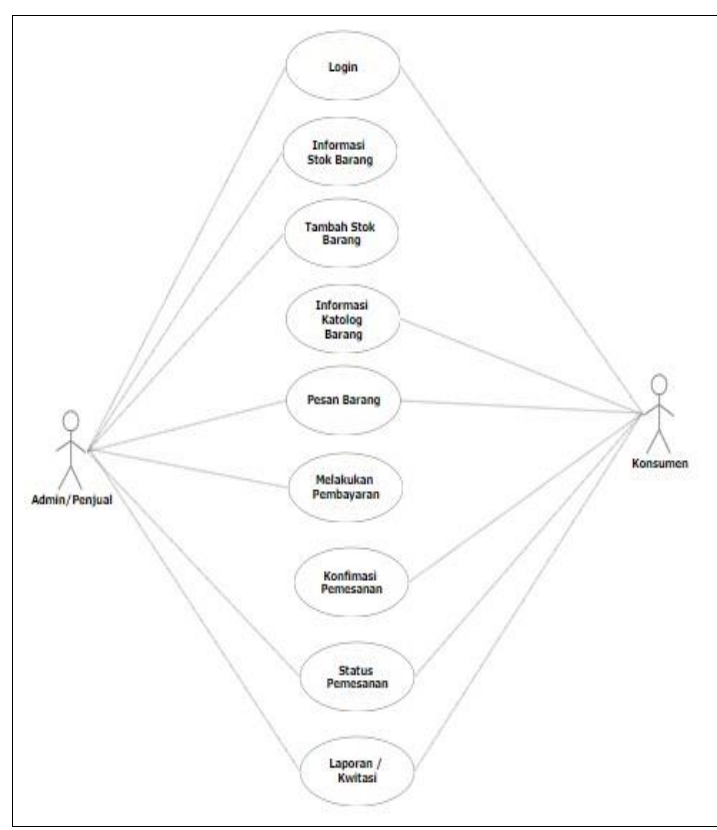

Gbr. 4 Use case diagram
4. Construction (code dan test), code merupakan tapah dalam penerjemahkan bentuk design kedalam code atau bahasa yang bisa dibaca oleh mesin. Kemudaian dilanjutkan dengan testing terhadap software Ruang Buku Indonesia dan code yang sudah dibangun, untuk mengetahui error yang mungkin terjadi untuk diperbaiki.

5. Deployment (delivery, support, feeback), deployment merupakan langkah implementasi software, pemeliharaan software, perbaikan software, evaluasi software, dan pengembangan software Ruang Buku Indonesia berdasarkan feedback yang diberikan, agar sistem Ruang Buku Indonesia bisa dijalankan dan dikembangkan.

\section{HASIL DAN PEMBAHASAN}

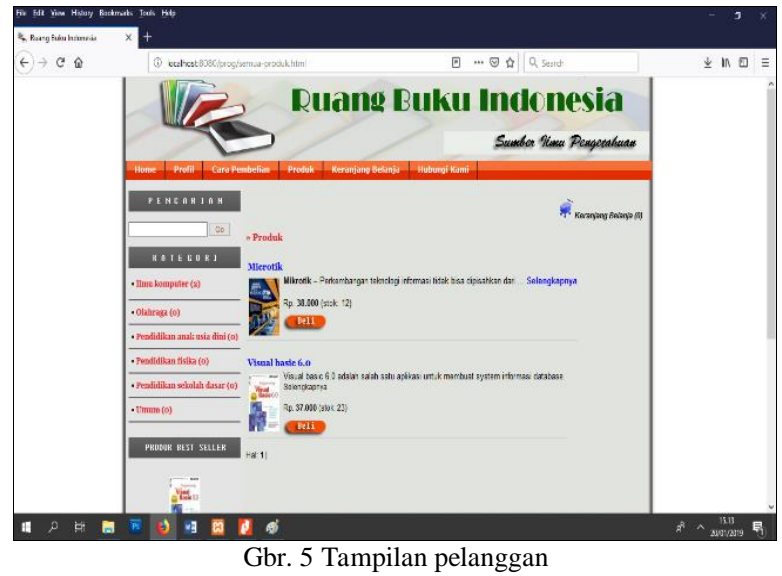

Pada gambar 5 merupakan tampilan yang dapat diakses oleh pelanggan atau konsumen adapun salah menu yang dapat diakses berupa cara pembelian, produk, keranjang belanja, katalog, produk best seller dan fasilitas pencarian. Pada gambar 6 merupakan tampilan index yang menampilkan produk baru yang diinput melalui halaman admin atau proses model. Tampilan index ini terdiri dari tampilan katolog dari masing-masing produk, menu katalog dapat ditambah melalui halaman admin menggunakan fasilitas model dan controller dan ditampilkan melalui fasilitas view.

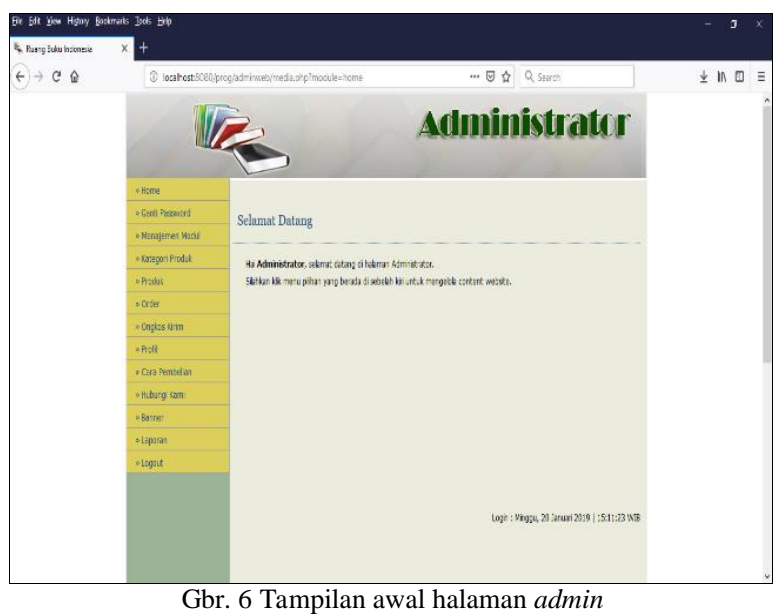


Tampilan gambar 6 merupakan tampilan yang pertama muncul ketika admin berhasil melakukan proses login. Halaman admin menampilkan menu-menu berupan ganti password, manajemen modul, katagori produk, produk, order, ongkos kirim, profil, carapembelian, Page 56 hubungi kami, benner, laporan, dan logout. Menumenu tersebut digunakan untuk mengolah data (model) yang dihungkan langsung kedalam database kemudian diproses (controller) dan ditampilkan dihalaman admin dan halaman konsumen sesuai dengan tempat view masing-masing.

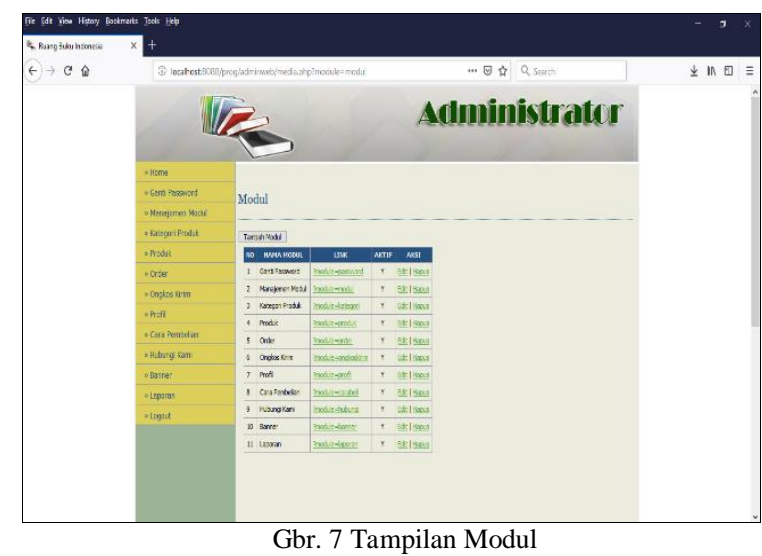

Tampilan gambar 7 merupakan tampilan modul yang digunakan untuk mengolah mепи-тепи ditampilan admin (untuk menambah menu atau untuk mengurangi menu). Halaman modul ini merupakan fasilitas model yang mempermudah admin dalam menambah menu-menu. Tampilan gambar 9 merupakan tampilan katagori yang digunakan untuk mengolah menu-menu katalog pada halaman komsumen apa menu katalog tersebut ingin ditambah atau dihapus.

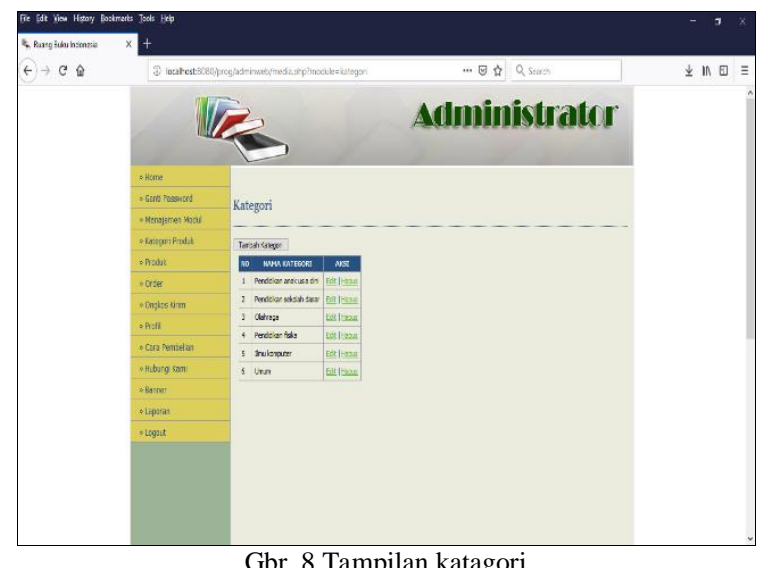

PENUTUP

Berdasarkan pembahasan yang ada, maka diperoleh beberapa kesimpulan :

1. Penelitian ini menghasilkan e-commerce berbasis model view controller (MVC),
2. Dalam penggunaan atau pengolahan e-commerce ini lebih mudah karena tidak perlu menggunakan coding lagi.

\section{REFERENSI}

[1] K. C. Laudon and J. P. Laudon, Essentials of management information systems. Pearson Upper Saddle River, 2011.

[2] S. Betha, Pemrograman Web dengan PHP. Bandung: Informatika, 2012.

[3] I. K. Suharsana and I. G. P. W. W. Wirawan, "Implementasi Model View Controller Dengan Framework Codeigniter Pada E-Commerce Penjualan Kerajinan Bali," J. Sist. dan Inform., vol. 11, no. 1, 2016.

[4] I. Solikin, "Perancangan Sistem Informasi Penjualan Bebasis Framework Model View cotroller (MVC) pada PT Thamrin Brother Cabang OKI," MEDIA Inform. DAN Komput., vol. 4, no. 1, pp. 74-91, 2014.

[5] R. A. Zulfikar and A. A. Supianto, "Rancang Bangun Aplikasi Antrian Poliklinik Berbasis Mobile," J. Teknol. Inf. dan Ilmu Komput., vol. 5, no. 3, 2018.

[6] I. Solikin and R. Amalia, "Materi Digital Berbasis Web Mobilemenggunakan Model4D," Jurnal Sistem Informasi, vol. 8, no. 3, pp. 321-328, 2019.

[7] C. S. D. Prasetya, "Sistem Rekomendasi Pada E-Commerce Menggunakan K-Nearest Neighbor," J. Teknol. Inf. dan Ilmu Komput., vol. 4, no. 3, pp. 194-200, 2017.

[8] R. T. Jurnal, "Pengembangan Rancang Bangun Sistem Kesiswaan dengan Menggunakan Framework Mvc (Model View Controller)," Kilat, vol. 7, no. 1, pp. 86-90, 2018.

[9] D. Wismarini and H. Murti, "Penggunaan Model View Controller (MVC) Dalam Perancangan Model Aplikasi Webgis Untuk Informasi Rentan Banjir Di Semarang," 2018.

[10] P. Sugiyono, "Metode penelitian kombinasi (mixed methods)," Bandung Alf., 2015.

[11] M. P. K. Sugiyono, "Kualitatif, dan Kombinasi (Mixed Methods)," Bandung Alf., 2013.

[12] M. Nazir, Metode Penelitian. Bogor: Ghalia Indonesia, 2014

[13] R. S. Pressman, "Rekayasa Perangkat Lunak: Pendekatan Praktisi." Andi, 2012 